\title{
Entrepreneurial curriculum in African universities: A panacea to graduates' unemployment if?
}

\begin{tabular}{|c|c|}
\hline \multicolumn{2}{|c|}{$\begin{array}{l}\text { Authors: } \\
\text { Chinyeake J. Igbokwe-lbeto }^{1} \\
\text { Florence C. Agbodike } \\
\text { Kehinde O. Osakede }^{3}\end{array}$} \\
\hline \multicolumn{2}{|c|}{$\begin{array}{l}\text { Affiliations: } \\
{ }^{1} \text { Department of Public } \\
\text { Administration, Eastern Palm } \\
\text { University, Nigeria }\end{array}$} \\
\hline \multicolumn{2}{|c|}{$\begin{array}{l}{ }^{2} \text { Department of Public } \\
\text { Administration, Namdi } \\
\text { Azikiwe University, Nigeria }\end{array}$} \\
\hline \multicolumn{2}{|c|}{$\begin{array}{l}{ }^{3} \text { West African Seasoning } \\
\text { Company Limited, Nigeria }\end{array}$} \\
\hline \multicolumn{2}{|c|}{$\begin{array}{l}\text { Corresponding author: } \\
\text { Chinyeake Igbokwe-Ibeto, } \\
\text { ugochinyerecj@yahoo.co.uk }\end{array}$} \\
\hline \multicolumn{2}{|c|}{$\begin{array}{l}\text { Dates: } \\
\text { Received: } 23 \text { Feb. } 2018 \\
\text { Accepted: } 28 \text { May } 2018 \\
\text { Published: } 16 \text { Oct. } 2018\end{array}$} \\
\hline \multicolumn{2}{|c|}{$\begin{array}{l}\text { How to cite this article: } \\
\text { Igbokwe-lbeto, C.J., } \\
\text { Agbodike, F.C. \& Osakede, } \\
\text { K.O., 2018, 'Entrepreneurial } \\
\text { curriculum in African } \\
\text { universities: A panacea to } \\
\text { graduates' unemployment } \\
\text { if?', Africa's Public Service } \\
\text { Delivery and Performance } \\
\text { Review 6(1), a222. https:// } \\
\text { doi.org/10.4102/apsdpr. } \\
\text { v6i1.222 }\end{array}$} \\
\hline \multicolumn{2}{|c|}{$\begin{array}{l}\text { Copyright: } \\
\text { (C) 2018. The Authors } \\
\text { Licensee: AOSIS. This } \\
\text { is licensed under the } \\
\text { Creative Commons } \\
\text { Attribution License. }\end{array}$} \\
\hline \multicolumn{2}{|l|}{ Read online: } \\
\hline 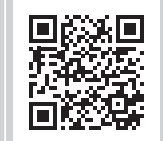 & $\begin{array}{l}\text { Scan this QR } \\
\text { code with your } \\
\text { smart phone or } \\
\text { mobile device } \\
\text { to read online. }\end{array}$ \\
\hline
\end{tabular}

Background: University education is a prerequisite for the production of highly competent experts which, in turn, contributes to economic growth and national development at large. For these to be achieved, the right entrepreneurial (content) curriculum and qualified teachers must be in place to perform this varied function.

Aim: Within the framework of human capital and cognitive theories - an eclectic approach this article examines the nexus between entrepreneurial curriculum in Africa and graduates employability with specific reference to Nigerian universities. To interrogate the issues raised, this article employed descriptive survey design and content analysis.

Setting: This study was carried out using qualitative desktop method in deriving data for answering the question. Over 50 literature were consulted and analysed in order to establish the nexus between entrepreneurial curriculum and graduate employability in Africa.

Methods: This research employed the descriptive survey method and content analysis with the researchers setting out to illustrate the association that exists between the dependent and independent variables.

Results: This article argues that the extent to which entrepreneurship education curriculum inculcates entrepreneurial skills among Nigerian undergraduates, is very poor. Also, the quality of resource persons employed to teach entrepreneurship education in the Nigerian universities appears not to possess the requisite knowledge to impart entrepreneurial spirit in students.

Conclusion: It concludes that the university authorities should ensure a 'fit' in the recruitment of entrepreneurial education lecturers as well as an adequate provision of teaching and learning aids.

\section{Introduction}

It is generally agreed that tertiary education is a sine qua non for human capital development. Tertiary education is a prerequisite for the production of highly competent experts which, in turn, contributes to economic growth and national development at large. For these to be achieved, the right entrepreneurial (content) curriculum and qualified teachers must be in place to perform this varied function. In recent times, many developing countries have realised that an early orientation to the practice of entrepreneurship is a necessary condition for the future appreciation and development of small and medium-scale enterprises (SMEs) for economic development. Some governments have a clear-cut deliberate policy to institute a systematic educational framework within which a meaningful SME can occur. However, in order to make this policy functional, our tertiary institutions and various other institutions must be charged with the task of creating sufficient indigenous trained and highly motivated entrepreneurs to manage the SME sector.

The university is an institution of higher learning and research which award academic degrees in a variety of subjects and provides both undergraduate and postgraduate education. One of the objectives of tertiary institutions, according to the National Policy on Education (2004), includes 'acquiring both physical and intellectual skills which will enable individuals to beself-reliant and useful members of the society'. Unfortunately, the possession of university degrees is no longer a guarantee for employment. Many young graduates continue to roam the streets in search of nonexisting jobs. This has led to a general feeling of despondency among them. Education which does not result in the ability to create ideas and transform such ideas into physical realities, is not the 
required education. Besides, the economic situation in the world, especially in developing countries such as Nigeria, appears to suffer from this fundamental problem; hence, there is need for direct national and international intervention for their immediate solution.

The high rate of graduate unemployment in Nigeria has been blamed on the fact that most graduates from Nigerian universities are unemployable (Chiaha \& Agu 2013). It is because of this high unemployment rate among graduates in universities that the National Universities Commission (NUC) introduced entrepreneurship education in the university curriculum as a compulsory course (Uzoka 2006).With the introduction of entrepreneurship education in the curriculum of Nigerian universities by the NUC, it becomes obvious that entrepreneurship education is considered an effective way of equipping graduates with the desired employability skills. Entrepreneurship education is unique in the sense that, unlike many other courses, it seeks to change people's attitudes and beliefs and to equip them with the skills necessary to plan, launch and also successfully manage their own business enterprises and that of others.

Today, one of the major problems facing Nigeria, in particular and Africa in general, is unemployment. At the beginning of 2016, the unemployment rate was at $10.4 \%$, by mid-year, the rate had increased to $12.1 \%$ with a year-end forecast of 18\% (Okoye, Igbokwe-Ibeto \& Osakede 2017). We are almost at 'the tipping point' when the unemployment may begin to push back against society and escalate open social dissension. The rate of graduates' unemployment is so alarming that it has defied national solution. Consequently, this social malady has triggered off all sorts of crime. As the saying goes 'an idle mind is the devil's workshop'. Crime wave in the country is at its peak, ranging from robbery, kidnapping, hired assassins, car snatching, stealing, vandalism, oil bunkering, political thuggery, cultism, internet fraud and so on. The unemployment situation is heightened by the proliferation of tertiary institutions that are churning out thousands of graduates each year without commensurate employment opportunities (Udobi 2008). The social malaise caused by this height of crime, has fast tracked the issue of insecurity of lives and property in the nation. However, over the years the quality of human capital produced by Nigerian universities has become a source of concern to employers of labour and all stakeholders. Inferential opinions have traced the problem to lack of entrepreneurial curriculum and incompetent teachers, infrastructure and funding (Igbokwe-Ibeto, Chukwemeka \& Okechukwu 2014). The situation in Nigeria is gloomy with seven out of ten graduates being unemployed, underemployed or simply unemployable as in 2016 (Okoye et al. 2017).

According to Anannagoon, Akudoand and Emetarom (2008), entrepreneurship education is novel in the curriculum of higher education in Nigeria. It would appear that only a few universities in the South East seem to have introduced it as a compulsory course. The few universities offering entrepreneurship education as a compulsory course of study, include the Nnamdi Azikiwe University Awka which has Chike Okoli Centre for Entrepreneurial Studies (COCES); the University of Nigeria, Nsukka which has a Centre for Entrepreneurship and Development Research (CEDR) structured to manage both Nsukka and Enugu campuses; Federal University of Technology Owerri which has a Centre for Entrepreneurial Studies (CES); and the Michael Okpala University of Agriculture, Umudike which operates a Centre for Entrepreneurship Development (CED).

The Nigerian population has been on steady increase, whereas job opportunities are getting leaner and leaner especially for graduates. Thus, unemployed graduates are scattered all over the country. Also, university education in Nigeria has had a tremendous expansion with increasing number of graduates, but then, most of these graduates are unemployable, because they do not possess the right and required skills to be employable or be self-employed. The situation of graduate unemployment has resulted in youth restiveness and all sorts of crime as earlier mentioned. A careful examination of the situation reveals that most of these graduates engage in these activities, because they lack requisite skills that could enhance employability or selfemployment. This lack of employability skills, resulting from inadequate and obsolete skill training in the Nigerian universities, has thrown university graduates into the labour market in search of jobs. This knowledge gap prompted the establishment of the entrepreneurship studies for the sole aim of inculcating entrepreneurial skills in prospective graduates. This implies that if the existing educational programmes and practices in our universities can enable students to acquire adequate skills and talents required by employers and also as self-employed individuals, these students would not often be unemployed upon graduation from university.

Flowing from the above, the implicit trust by policy-makers is that entrepreneurship education, as currently designed can impact significant entrepreneurial skills in Nigerian university undergraduates. This article therefore examines the impact of entrepreneurship education on the enhancement of entrepreneurial skills among undergraduates in Nigeria. This article seeks to address the following three research questions: (1) To what extent could entrepreneurship education curriculum be a panacea for graduate's unemployment predicament in Nigeria?; (2) To what extent are the right resource persons used towards producing self-reliant graduates in Nigeria?; (3) To what extent are facilities put in place towards inculcating entrepreneurial skills among Nigerian university undergraduates?

\section{Methodology}

In order to analyse how Nigerian graduates employability could be enhanced through entrepreneurial curriculum in Nigerian tertiary institutions, this research employed the descriptive survey method and content analysis, with the 
researchers setting out to illustrate the association that exists between the dependent and independent variables. The researchers' main goal in a descriptive study is to describe accurately the relationship between two phenomena (entrepreneurial curriculum and graduates employability). This method is useful, because the article is interested in finding the meaning and to obtain an understanding of the issues under investigation. The study relied heavily on secondary source of data which were sourced from academic literature on the subject matter.

\section{The conceptual and theoretical underpinning}

In discussing issues salient to this topic, it is pertinent to consider clarification of some concepts in order to situate them within the context of our discussion. It is generally believed that the entrepreneur is a risk-taker who comes up with fresh ideas, and makes good decisions about opportunities and potential projects. An entrepreneur is the original, the sole and the ultimate creator of wealth (Udeh 1999). Ogundele in Ezenylimba, Nwobuand Ezeanyika (2011) defines an entrepreneur as the individual who initiates and nurses to growth a new and ongoing business organisation where none existed before. Entrepreneurs are opportunity seekers, promoters and rebrander who can scan the environment and coordinate resources (money, man, material and information) to achieve or realise a business objective. Entrepreneurship education inculcates in individuals skills that could enable them to confront situations in creative and normative ways (Chiaha \& Agu 2013). They went further to explain that such entrepreneurial individuals create jobs for themselves and others, and thereby reducing unemployment (Chiahaand Agu 2013).

Offorman (2000) conceived entrepreneurship education as a formal structure instruction that conveys entrepreneurial knowledge and develops in students a focused awareness relating to opportunity, recognition and the creation of new ventures. Entrepreneurship education aims at inculcating in an individual the ability to seek information and advice, make decisions, plan one's time and energy, carry through an agreed responsibility, communicate and negotiate, deal with people in power and authority, solve problems, resolve conflicts, evaluate performance and sue feedback to improve, cope with stress and tension, and achieve self-confidence (Agu, Chiaha \& Ikeme 2013). Entrepreneurial skills are said to be the necessary set of skills required to be an entrepreneur. Agu et al. (2013) argue that entrepreneurial skills must be nurtured through proper education so that it can be directed to responsible and enriching small business endeavours that will benefit the individuals and the communities in which the entrepreneurs live. Creativity is one of the entrepreneurial skills which could be imparted and acquired through entrepreneurship education.

Curriculum is an important element of education. This is because of the fact that the aims of education are reflected in the curriculum. It is through curriculum that the general aims of school education receive concrete expression. Curriculum is a group of related courses, often in a special field of study.

Entrepreneurial studies are very vital in all levels of our educational systems. Nigeria needs entrepreneurial studies for economic stability and to overcome her weeping unemployment predicament. The NUC in 2004 introduced entrepreneurial studies in all Nigerian universities. The then secretary of the NUC Okebukola (2005), said:

For all the programmes, we have thrown out old concept, old topics, we made the orientation of the curriculum more practical we have put in entrepreneurial studies so that... when you leave the university with a certificate and are able to start your small business, access some credit and be self-reliant, self-employed and self-sufficient. (p. 20)

What Nigeria's tertiary institutions need is quality education, functional and self-reliant education and, of course, education that can place three square meals on one's table daily. One of the major goals of National Policy on Education for tertiary education is to acquire both physical and intellectual skills that will enable individuals to be self-reliant and useful members of the society. It is a truism that entrepreneurial studies have been introduced in the universities and it is also factual that the practical aspect of entrepreneurial studies is not taught in most universities, as a number of the universities have neither entrepreneur workshops nor skill acquisition centres. Even where available, they are not functional. The undergraduate students are not scheduled for industrial training programmes (IT) where they can practice what they have learnt. The issue of IT is a sine qua non for these would-be graduate entrepreneurs. During the IT period, which should last between 6 months and 1 year, the students should be able to learn enough and equip themselves with practical knowledge for self-sustenance and self-reliance. They should be exposed to skills such as processing of marble, plumbing, painting, quarrying, crop farming and livestock farming, hair dressing, bookbinding, computer application, printing, shoemaking, dyeing of cloth, and soap and pomade making; regrettably, this is not the case.

The role of entrepreneurship studies in the development process cannot be over emphasised. According to Naude (2008), effective entrepreneurship venture fosters the production of wealth for a nation, creates job that utilises human resource and also reduces economic waste. He went further to argue that the income level of the average person and standard of living of the society, at large increase with every successful entrepreneurship project. No wonder Naude (2007) acknowledges that entrepreneurship originated out of trade by barter. In the words of Ejiofor (1991), entrepreneurship is the first step towards a self-reliant economy that can generate internal self-sustaining economic growth and development. On the same vein, Bruck (2006) states that entrepreneurs occupy a central position in a market economy and there are never enough of them. A society is adjudged prosperous only to the degree to which it rewards 
and encourages entrepreneurial activity. Entrepreneurial activities are the critical determinants of the level of success, prosperity, growth and opportunity in any country.

As is the tradition in social and management sciences, no one theoretical approach can adequately explain a social phenomenon. Nonetheless, we need a platform on which to anchor our subject of analysis. Of all available theories that could be used to unravel our subject matter of investigation such as labour productivity theory with its three sub-theories of efficiency, effectiveness and performance, the human capital and cognitive theories, an eclectic approach, are perhaps the most potent. According to Schultz (1988), human capital theory holds that the well-being of a society is a function not only of the traditional stocks of financial capital, labour and natural resources, but also of the knowledge and skills of individuals. This theory predicts that increased knowledge and skill will yield improved economic outcomes for both individuals and societies, especially in modern societies where it is widely held that knowledge and skill convey a greater economic and social premium than in the past. Human capital theory is relevant and applicable to the article, because higher education is a key element of human capital theory. It is viewed as the primary means of developing knowledge and skill. Most research around the human capital development and education is based on Mincer's human capital earnings function, which predicts that earnings are a function of educational attainment and work experience. According to Adedeji and Campbell (2013), there is evidence that human capital development is a strong influence on educational policy, with statements to this effect being found in the goal and mission statements of many educational agencies and jurisdictions.

Cognitive theory, as propounded by Taylor (1999), assumes that individuals do not possess a perfect knowledge of the world, because there is too much information out there to handle. As a result of this, they have to select information and interpret them based on their previous experiences and thus see and know the world differently. Behavioural patterns are the products of two psychological processes. The first process operates through the selection of environments and the second through the product of environments. When people have gained certain preferences and standards of behaviour, they tend to choose activities and individuals who share the same set of preferences and thereby mutually reinforcing preexisting personal inclinations and fixed courses of actions.

Precisely, the individual characteristics leading to an entrepreneurial career are only activated when exposed to a favourable socialisation process, where an entrepreneurial career is as a viable possibility among others. Thus, the social environment is of primary importance to foster future entrepreneurs. The general idea is that individual characteristics are precursor traits and in the context of a given 'cafeteria of experiences' help to determine both how experiences are weighted or attended to and how the individual reacts to those experiences. That is, individuals will only activate their entrepreneurial potential if they have a certain specific ability and sensitivity. There are environmental possibilities only if they have social support.

These three prerequisites must be fulfilled if actions are to be taken to become an entrepreneur. Actually, this interaction between ability or skills, environmental possibilities and social support is likely to lead to a positive reinforcing spiral where the entrepreneur is supported and therefore can further develop his specific set of skills. Hence, basic intelligence, coupled with an interest in becoming an entrepreneur, leads the individual to develop the skills needed to become successful. This theory explains why people engage in an entrepreneurial behaviour. Thus, the social environment is of primary importance to foster future entrepreneurs. The general idea is that individuals will activate their entrepreneurial potential if there are environmental possibilities and also if they have social support. According to empirical literature, entrepreneurial potential could be activated through entrepreneurship education, because entrepreneurship education equips individuals with adequate skills to be successful in life (Chiaha \& Agu 2013).

The relevance and applicability of cognitive theory in this article enables us to have a better understanding of why people engage in entrepreneurial behaviour. The relevance of this theory is that it makes it possible to have a better understanding of the interaction between the characteristics of the situation and the characteristics of the entrepreneur. In other words, there is a movement from studying the personality of the entrepreneur to studying the situations that lead to entrepreneurial behaviour. Behaviour is heavily based on how individuals perceive the situation or environment and how the environment is presented to them.

Also, anchoring this article on this theory becomes pertinent in the sense that the teaching and learning of entrepreneurship education releases the entrepreneurial potentials of students and thereby enabling them to secure jobs after school or at best becoming self-employed through the establishment of their own businesses through the plethora of knowledge and skills they may have acquired during their stay in school. In addition, the theory explains that individuals activate entrepreneurial potentials when there are environmental possibilities. The environmental possibility in question here is the teaching of entrepreneurship education. This means that with entrepreneurship education, individual's entrepreneurial potentials and skills are enhanced and thereby enabling them to develop skills that will be of great benefit to them and society at large.

\section{The interface between entrepreneurial curriculum and graduates' employability}

According to Collins and Druten (2003) and Igbokwe-Ibeto et al. (2014), researchers have produced compelling evidence for the causal link between entrepreneurial curriculum, 
qualified teachers and graduates employability. They argue that the effectiveness of human resource practices, particularly training and development, often have a direct bearing on productivity and service delivery.

For example, Chiaha and Agu (2013) conducted a study on entrepreneurship education and graduate employability in Nigeria. The purpose of the study was to investigate entrepreneurship education and employability of university graduates in Nigeria. The researchers established that entrepreneurship education enables graduates to possess employability skills. Entrepreneurship education inculcates employability skills and consequently leads to high entrepreneurial index of the graduates. Eziama (2002) did a study on entrepreneurial skill needs of women in small-scale enterprises in Imo state, Nigeria. The findings of the study show that women entrepreneurs, operating small-scale enterprises in Imo state, require entrepreneurial skills such as managerial skills, personality and human relations skills, marketing skills, financial management and accounting skills. Agbogidi (2007) did a study on entrepreneurial skills required by automechanics technology students in the technical colleges for establishing SMEs in Delta state. The researcher found that efficiency in automobile repairs and other areas requires that workers be given skills and knowledge adequate to handle the work that they perform. These skills include managerial skills, financial management skills, marketing skills and communication skills. Obi (2001) carried out a study on communication skills needed by university graduate employees for successful job performance in business organisations. The findings of the study indicate that employees differed in their rating of the importance of writing, speaking, reading and listening skills required by university graduate employees for successful job performance, but not significantly. The study concluded that university graduate employees were perceived deficient in all the four clusters of communication skills.

Graduates with the right entrepreneurial training, appear to have a comparative advantage in understanding and adapting to new or existing ideas, production processes and service delivery. At this juncture, it is important to define the concept tertiary institution. Contemporarily, the university is an institution of higher learning with powers to award or confer degrees, diplomas and certificates. For Ross in Asobie (2001), university is:

A self-governing community with an elected hierarchy, separated from the world of commerce, involved in a mission to learn and to teach at an advanced level, using mysterious ritual and dress to dramatize its uniqueness, and requiring from its members, deep loyalty and enduring support for each other and the university. (p. 27)

In the words of Max Weber, an influential German sociologist and greatest apostle of bureaucracy the, bureaucratic institution has a well-designed mechanism within which all the component parts work efficiently without distraction, towards clearly defined goals (Weber 1947). Efficiency here refers to the relationship between input and output. An efficient entrepreneurial curriculum produces maximum output with minimum input for any given quantity and quality (see Eneanya 2009). Although there are other features of bureaucracy, the researchers focus on efficiency, because this article is examining the relationship between the quality of input (entrepreneurial curriculum) and the quality of output (graduates and their employability). Corroborating this debate, Spreight in Arhuidese (2003) argues that 'an institution is technically efficient if it is adequate to the demand on it'. Adequacy here implies competence and capacity to deliver the goals, that is, to attain it. Subsequently, an efficient policy may be ineffective, because its activities, although efficient, are not sufficiently directed at goals and therefore not achieving such goals. Thus, efficiency is different from effectiveness. The former emphasises means, while the latter emphasises the end of programmes (Igbokwe-Ibeto 2011). The highpoints of Weber's arguments are that an ideal bureaucracy is one in which there exist functional specialisation, hierarchy, impersonal relationship, standard procedure and rules, authority, legitimacy, efficiency and competence or fitness. The university system, having these features of bureaucracy, makes it a bureaucratic institution.

\section{Challenges confronting entrepreneurial education in the Nigerian universities}

Replicating the title of this article, which reads 'Entrepreneurial Curriculum in African Universities: A Panacea to Graduates' Unemployment if ... 'the 'if' that ended the title simply means enabling environment and other challenges facing students in the process of acquiring the desired entrepreneurial education. Some of the challenges are listed as follows:

- Unfavourable curriculum: The extent to which entrepreneurship education curriculum inculcates entrepreneurial skills in undergraduates is very poor.

- Entrepreneurial studies is allocated little time in the school timetable (once a week) while students are not given opportunity for IT.

- Poor funding of the universities and inadequate entrepreneurship education facilities such as adequate hall for teaching and learning of entrepreneurship education, and Information and Communication Technology (ICT) gadgets are not adequately provided for students as well as in adequate entrepreneurial skills acquisition equipment.

- Students are not exposed to facilitators or practical trainers who can organise workshops and seminars. Also, the entrepreneurship education pedagogies used by lecturers in the universities are poor.

- Poor facilities like incessant power outage, poor network of roads and lack of pipe borne water. Yet, after graduation, government is hesitant in giving soft loans to graduate business starters.

- The quality of resource persons used to teach entrepreneurship education in the Nigerian universities is poor. Most of the lecturers in entrepreneurship education appear not to possess the requisite knowledge to impart entrepreneurial skills in undergraduates. 
- Banks' lending interest rates are very high as well as demanding collaterals which the young entrepreneurs can hardly afford. Yet, harsh government policies on business taxes and insecurity of lives and property in Nigeria have not galvanised the system.

It is the above-listed challenges and unconducive environment that faces the graduate entrepreneur today in Nigeria that represent the 'if' with three dots (...) in the topic of this article. It is one thing to learn a skill or trade and another to put that skill into practice. If the enabling environment for exhibiting the knowledge or business idea is not conducive, the business idea dies a natural death. Entrepreneurial studies in the universities will be meaningful when these challenges are resolved and students will be well exposed to the study. Having acquired good theoretical and practical knowledge of entrepreneurship, one can proudly say that our graduates will be self-reliant and self-employed and can be employers of labour.

\section{Entrepreneurial curriculum in Nigerian universities and graduates' employability: The way forward}

Having identified the challenges confronting entrepreneurial curriculum and education in Nigerian universities towards graduate employability, as huge and complex as they appear to be, they are not insurmountable. In this section, we shall examine some steps that, if taken, could ameliorate the issue of graduate unemployment in Nigeria.

Higher institutions of learning and technical vocational educational training programmes should periodically revise their curricula and focus on fields of study which have a high market demand to absorb young graduates. Indeed, they should be able to create a linkage among potential government institutions, private companies and industries, international and non-governmental organisations (NGOs), as well as other stakeholders to enhance schools to work towards transition (Dibie \& Dibie 2014).

The university authorities should ensure a 'fit' in the recruitment of lecturers as well as the adequate provision of comfortable lecture halls and seats that are equipped with requisite teaching and learning aids such as projectors, marker boards, public address system, properly ventilated and well-lit classrooms. Additionally, the government should ensure the provision of information and communication facilities such as a steady internet access, distribution of laptops and other computer devices to aid learning.

Considering the fact that the methods employed by lecturers in teaching entrepreneurship education in Nigerian universities are inadequate and obsolete, it is recommended that lecturers should be more receptive to the idea of adopting new and modern ways of teaching the subject matter. The government through the National Universities Commission can set up special grants for frequent training and retraining of lecturers within and outside the country to bring them up-to-date with modern ideas and teaching methods of the subject matter. In other words, appropriate pedagogies should be used in delivering entrepreneurship education. Contents (curriculum) should be derived from industry and market requirements.

The universities, federal and state governments should also provide adequate skills acquisition machines and equipment to facilitate the empowerment of our teaming youthful population as well as provide loans or capital to enable them to startup businesses after graduation from the tertiary institutions having been imparted with entrepreneurial skills.

If Nigerian graduates are to be relevant in this new era and very competitive global economy, all stakeholders should strengthen cooperation and partnerships to ensure that returns from both formal and non-formal education galvanise highly productive outcomes in the labour market.

National Universities Commission should ensure the constant monitoring and evaluation of the activities of stakeholders responsible for the implementation of the goals of government as it pertains to entrepreneurship education and curriculum. Such relevant stakeholders include lectures, respective school administrations and other non-academic staff.

\section{Concluding remarks and implications}

We commenced this article by having an overview of the issue (entrepreneurial curriculum in Africa and Nigerian universities in particular) and its imperative in graduate unemployment predicament, followed by review of the concept of education, concept of university education, concept of entrepreneurship, concept of entrepreneurial skills and concept of entrepreneurship education which is defined as the type of educational process geared towards equipping students with creative and innovative ideas that will enhance their self-employment and job creation. We also examined two theories related to this article, namely human capital theory and cognitive theory with a view of establishing intellectual cobweb surrounding the issues of entrepreneurial curriculum in Nigerian universities and how it could leverage graduate unemployment. The human capital theory argues that the well-being of a society is a function not only of the traditional stocks of financial capital, labour and natural resources, but also of the knowledge and skills of individuals. The theory admonishes that increased knowledge and skill will yield improved economic outcomes for both individuals and societies, especially in modern societies where it is widely believed that knowledge and skill convey a greater economic and social premium than in the past. The cognitive theory explains why people engage in an entrepreneurial behaviour.

Also, empirical studies, related to the issues raised in this article, were reviewed. The reviewed studies covered entrepreneurship education, entrepreneurial skills and 
undergraduate skill development. Indeed, none of these studies found a negative relationship between entrepreneurial curriculum and graduates employability. This implies that with the right and conducive environment, entrepreneurial curriculum in our tertiary institutions is a panacea to graduate unemployment in Nigeria.

Flowing from the above, the following conclusions, which addressed the research questions, have been reached. The extent to which entrepreneurship education curriculum inculcates entrepreneurial skills in undergraduates is very poor. The quality of resource persons used and the methodology employed by lecturers in teaching entrepreneurship education in Nigerian universities are inadequate and obsolete. This can be seen in their unwillingness to embrace novel and modern ways of teaching the course such as the use of live samples, simulations, demonstrations using modern machines and devices as well as guided excursions to factories, companies and corporate organisations owned by entrepreneurs.

Last but not the least, this article argues that entrepreneurship education facilities such as adequate halls and seats for the teaching and learning of entrepreneurship education, ICT services, equipment for skills acquisition and so on are either inadequate or non-existent.

The findings of this article have some far-reaching implications for all stakeholders and partners in national development. First and foremost, the findings of this article have supported empirical evidence that entrepreneurship education is the only viable alternative for solving the huge unemployment challenge in our country and Africa in general. However, considering the fact that this novel approach to problemsolving is currently facing problems of its own, it becomes imperative to state categorically that if these challenges, as examined and outlined in this article, are not tackled, the objective for introducing the entrepreneurship education may not be achieved. The university and other relevant stakeholders in the educational sector should note that there is need to revamp, revive and be receptive to the injection of new and creative ideas in the teaching of the entrepreneurial education. Yet, it harpoon on the need for the improvement of the general infrastructural facilities deployed in the teaching of entrepreneurial education in Nigeria with a view to churning out graduates who are able to empower themselves and their immediate environment, and the entire society at large. Also, if the problem of funding is not quickly addressed, it may defeat the essence of entrepreneurship education.

\section{Suggestion for further study}

In the configuration of graduate unemployment in Nigeria and Africa, there are other variables and parameters beyond the obvious lack of social environment and social support, entrepreneurial training and skilled trainers in the universities. Further researches could be conducted on identifying other factors responsible for graduate unemployment in these economies and what percentage of the total problem can be attributed to the lack of entrepreneurial content in university education.

\section{Acknowledgements}

We acknowledge all authors whose works were cited in this article as well as our families, friends and well-wishers in the intellectual community

\section{Competing interests}

The authors declare that they have no financial or personal relationships which may have inappropriately influenced them in writing this article.

\section{Authors' contributions}

F.C.A. did the research materials collation, C.J.I.-I. did the writing and K.O.O. did the editing.

\section{References}

Adedeji, A.S. \& Campbell, O.S., 2013, 'The role of higher education in human capital development', viewed 15 August 2014, from http://ssrn.com/abstract= 2380878

Agbogidi, A.l., 2007, 'Entrepreneurial skills required by auto mechanics technology students in the technical colleges for establishing small and medium scale enterprises in Delta state', an Unpublished MED Thesis, Department of Educational Foundation, Faculty of Education, University of Nigeria, Nsukka.

Agu, R.A., Chiaha, G.T.U \& Ikeme, A.I., 2013, 'A paradigm shift in entrepreneurship education pedagogy in Nigeria: Issues that must be confronted to evolve best practice', paper presented at entrepreneurship seminar at University of Mkar, Mkar, 26-28 August.

Anannagoon, B., Akudo, F. \& Emetarom, U., 2008, 'Student's perception on entrepreneurship education in higher institutions and poverty alleviation for sustainable development in Abia state Nigeria', paper delivered at the 2008 International Conference of the Nigerian Association for Educational Administration and Planning, 23rd-27th September.

Arhuidese, J.E., 2003, Target setting and performance measurement for public and private sector, Global forum for manpower development: Developing human resources skills held for CBN Directors in Jos, 11-13 October, pp. 1-11.

Asobie, A., 2001, 'Nature and ethics of university administration', in I. Olojede \& B. Fajonyomi (eds.), Ethics and public accountability in Nigeria, A-Triad Associates, Lagos., pp 46-49.

Chiaha, G.T.U. \& Agu, R.A., 2013, Entrepreneurship Education and graduate employability in Nigeria, a paper presented at a conference on transforming African higher education for graduates employability and socioeconomic development organized association of African universities Libreville Gabon

Collins, R. \& Druten, K., 2003, Human resource management practices, viewed 26 November 2013, from http://www.edu.au/agsm/web.agsm.nsf/AttachmentByTitle/ CCHREPORT2003/\$FILE/C

Dibie, R. \& Dibie, J., 2014, 'The dichotomy of capacity building and unemployment in Ethiopia', Africa's Public Service Delivery and Performance Review 3(2), 25-76. https://doi.org/10.4102/apsdpr.v2i3.59

Ejiofor, P. N., 1991, Management in Nigeria: Theories and Issues, Africana Educational Publishers (Nig.) Ltd, Onitsha.

Eneanya, A.N., 2009, Principles and practice of public personnel administration in Nigeria, Concept Publications Limited, Lagos.

Ezenylimba, E., Nwobu, T. \& Ezeanyika, B., 2011, 'Entrepreneurial marketing oriented curriculum and Nigeria's economic development in managing public private partnership for Africa's prosperity', in A. Kamnebe (ed.), Managing Public Private Partnership for Africa's Prosperity, pp 98-106, Rex Charles \& Patrick Ltd. Publishers, Nimo.

Eziama, I.C., 2002, 'Entrepreneurial skill needs of women in small-scale enterprises in Imo state',an Unpublished MED Thesis, Department of Educational Foundation, Faculty of Education, University of Nigeria, Nsukka.

Igbokwe-lbeto, C.J., 2011, 'The role of human resource management in mitigating global financial crisis', International Journal of Social Sciences and Humanities Review 2(4), 115-128. https://doi.org/10.4102/apsdpr.v2i3.62

Igbokwe-Ibeto, C.J., Chukwuemeka, E. \& Okechukwu, E., 2014, 'Enhancing human capital development and service delivery in Nigerian tertiary institutions through effective academic staff recruitment', Africa's Public Service Delivery \& Performance Review2(3), 125-152. 
N.P.E (FRN)(2004), National policy on education $4^{\text {th }}$ edition, Abuja: Federal Ministry of Education.

National University Commission (NUC), 2004, Labour market expectations of Nigerian graduates, Education Tax Fund (ETF), Nigeria.

Naude, W.A., 2007, 'Peace, Prosperity, and Pro-Growth Entrepreneurship', WIDER Discussion Paper 2007/02, UNU-WIDER: Helsinki.

Naude, W., 2008, Entrepreneurship in economic development, Research paper No. $2008 / 20$ presentenced at the world institute for development economics research (WIDER), United Nations University.

Obi, I.O., 2001, 'Communication skills needed by university graduate employees for successful job performance in business organizations', an Unpublished MED Nigeria, Nsukka.

Offorman, P.C., 2000, Teaching entrepreneurship in vocational education, Centevour Press Limited, Calabar.

Okebukola, P., 2005, 'Why varsities cannot admit more than 147,000 candidates this year?', The Guardian, 13 October, p53.
Okoye, J.C., Igbokwe-lbeto, C.J. \& Osakede, K.O., 2017, 'Youth unemployment and human capacity development in Nigeria: The imperatives of entrepreneurship education', Conference Proceedings, Faculty of Management Sciences, Nnamdi education', Conference
Azikiwe University, Awka.

Schultz, T., 1988, 'Education investment and returns',in H. Chenery \& T. Srinivasan (eds.),Force on higher education and society: Handbook of development economics, University of Chicago Press, North Holland.

Taylor, M.P., 1999, 'Survival of the fittest? An analysis of self-employment duration in Britain', The Economic Journal 109, C140-C155.

Udeh, J., 1999, Entrepreneurship in the 21st century, CIDJAP Publication, Enugu.

Udobi, J.I., 2008, 'Repositioning Nigeria's tertiary education for Relevance - In a knowledge based economy', POFSA Journal of Arts, Science and Technology, 3(4):13-24.

Uzoka, F.A., 2006, 'Challenges in entrepreneurship in home economics education', Nigeria Journal of Education 4(2), 98-106.

Weber, M., 1947, The theory of social and economic organization translated by A.M.B Henderson and T. Parsons, Free Press, New York. 